\title{
STUDI GOLDEN SECTION PADA FASADE BANGUNAN DI KAWASAN KAYUTANGAN, MALANG
}

\author{
Wulan Astrini, Indyah Martiningrum, dan Muhammad Satya Adhitama
}

\author{
Jurusan Arsitektur, Fakultas Teknik, Universitas Brawijaya \\ wulanastrini@yahoo.com
}

\begin{abstract}
ABSTRAK
Penelitian tentang studi golden section pada fasade bangunan di kawasan Kayutangan, Malang ini memiliki tujuan spesifik yaitu (1). Mengevaluasi proporsi fasade bangunan di Kayutangan, Malang berdasarkan teori golden section dan (2). Menghasilkan rekomendasi desain fasade bangunan di Kayutangan, Malang yang proporsional dan sesuai dengan golden section. Metode pengumpulan data menggunakan observasi terhadap fasade bangunan di dua sisi koridor jalan tersebut dengan instrumen distance meter, kemudian digambarkan komposisinya secara digital secara dua dimensi. Selanjutnya data dianalisis proporsinya menggunakan golden section dan dilanjutkan dengan membuat simulasi digital khususnya untuk fasade bangunan yang proporsinya tidak sesuai dengan golden section. Hasil penelitian ini menunjukkan bahwa fasade bangunan di Kayutangan, Malang $10 \%$ memiliki proporsi lebar dan tinggi bangunan sesuai dengan golden section dan $90 \%$ tidak sesuai dengan golden section. Hasil penelitian ini diharapkan dapat menjadi rekomendasi desain bagi penataan dan pembenahan estetika kota, khususnya di kawasan Kayutangan, Malang maupun dapat menjadi rujukan bagi pihak-pihak yang ingin melakukan studi sejenis di kawasan lainnya.
\end{abstract}

Kata kunci: golden section, fasade bangunan

\begin{abstract}
The study of the golden section in the building facade in Kayutangan, Malang has a specific purpose, namely (1). Evaluate the proportion of building facade in Kayutangan, Malang based on the theory of the golden section and (2). Produce design recommendations of building facade at Kayutangan, Malang which proportionate and in accordance with the golden section. Data collection method using observations of the building facade on both sides of the corridor with a distance meter instrument, then the composition is described as a two-dimensional digitally. Furthermore, the data were analyzed using the golden section proportion, followed by making a digital simulation, especially for building facade that is not in accordance with the proportion of the golden section. The results of this study indicate that the building facade in Kayutangan, Malang has a proportion of $10 \%$ of the width and height of the building according to the golden section and $90 \%$ are not in accordance with the golden section. The results of this study are expected to be recommendations for structuring the design and aesthetic improvement of the city, particularly in Kayutangan, Malang and can be a reference for those who want to do similar studies in other regions.
\end{abstract}

Keywords: golden section, building facade 


\section{Pendahuluan}

Kota Malang merupakan salah satu kota besar di Jawa Timur yang memiliki bangunan-bangunan berarsitektur kolonial di beberapa kawasan, baik bangunan yang berfungsi sebagai rumah tinggal, pertokoan, rumah makan, sekolah, maupun perkantoran. Salah satu kawasan bersejarah yaitu Jalan Basuki Rahmat atau yang dikenal dengan kawasan Kayutangan. Jalan Basuki Rahmat merupakan jalan utama menuju pusat kota Malang yang sudah digunakan sejak keberadaan pemerintah kolonial Belanda. Saat ini kawasan Kayutangan memiliki berbagai aktivitas guna lahan seperti perdagangan, jasa, perkantoran, serta peribadatan yang mengakibatkan adanya perbedaan yang signifikan pada karakteristik fasade bangunan kolonial dan modern. Di sisi lain adanya beberapa bangunan komersial yang kosong akan mempengaruhi tampilan kawasan secara keseluruhan.

Kondisi fasade bangunan tersebut turut mempengaruhi kualitas estetika kota Malang dan memberikan citra kota yang spesifik dan membedakannya dengan yang citra kota lainnya. Perancangan koridor kota berkaitan dengan tanggapan pengindraan manusia terhadap lingkungan fisik seperti penampilan visual, kualitas estetika dan karakter spasial koridor, sehingga nilai estetika visual yang mampu merepresentasikan isi atau ruang kota menjadi faktor yang sangat dibutuhkan dalam melakukan upaya penataan koridor jalan khususnya jalan masuk kota. Fasade bangunan merupakan tampilan atau wajah bangunan yang dapat mengekspresikan ciri/karakter khas bangunan maupun fungsi bangunan tersebut. Oleh sebab itu, fasade bangunan memiliki peran terpenting dalam arsitektur, karena merupakan bagian yang pertama kali dilihat oleh para pengamat. Demikian pula halnya dengan estetika kota sangat dipengaruhi kualitasnya pertama kali oleh tatanan/komposisi fasade bangunan-bangunan di kanan-kirinya.

Kualitas estetika fasade bangunan dapat dipengaruhi oleh proporsi antara kepala, badan, dan kaki maupun proporsi elemen-elemen lainnya seperti dimensi jendela, pintu, dan ventilasi terhadap kepala, badan, atau kaki bangunan maupun terhadap keseluruhan fasade bangunan. Teori proporsi yang banyak digunakan dalam arsitektur yaitu golden section. Golden section mempunyai sifat-sifat aljabar dan geometris yang luar biasa, yang dihitung untuk keberadaannya di dalam arsitektur maupun di dalam struktur organik yang hidup. Setiap pertambahan didasarkan pada golden section sekaligus merupakan penambahan dan geometris (Ching, 2000:286). Sehubungan dengan proporsi fasade bangunan di kawasan Kayutangan, Malang, maka dapat dievaluasi ketepatan proporsinya dengan menggunakan golden section, sehingga dapat diketahui apakah proporsi fasade bangunan-bangunan di kawasan tersebut sudah tepat atau belum. Di samping itu, dengan mengetahui proporsi pada fasade bangunan di kawasan Kayutangan, Malang, maka dapat dipahami pula bagaimana sistem proporsi fasade bangunan yang utamanya bergaya arsitektur kolonial dengan fungsi perkantoran, pertokoan, dan tempat peribadatan.

\section{Bahan dan Metode}

\subsection{Citra Kota dan Estetika Kota}

Citra kota adalah gambaran mental dari sebuah kota sesuai dengan rata-rata pandangan masyarakatnya (Zahnd, 2009:53). Estetika kota merupakan salah satu elemen dari delapan dimensi lanskap kota yang dijelaskan oleh Meinig (1971:1) dalam Heryanto (2011:14-15), dimana lanskap kota merupakan suatu dimensi dari berbagai isu yang berkaitan dengan pembangunan, perubahan, dan pengelolaan dari kota dan perdesaan. Oleh sebab itu, citra kota juga dipengaruhi oleh estetika kota, karena lanskap kota merupakan bagian dari perancangan arsitektur kota. Menurut Zahnd (2009:167-171) terdapat tiga faktor estetika kota yaitu orientasi, posisi, dan isi 
a. Zahnd (2009:172-175) juga menjelaskan ada tujuh prinsip sebuah place (kota) secara estetis, yaitu keseluruhan sebagai unit, bentuk unit, kekosongan pusatnya, penutupan batasnya, hubungan lahan/tampak, perabotan tempat, dan gambaran visual. Dari ketujuh prinsip tersebut yang berhubungan langsung dengan studi proporsi fasade bangunan dalam penelitian ini yaitu:

b. Bentuk unit

c. Sebuah place sebagai unit seharusnya memiliki bentuk yang sejelas mungkin dalam hal tipologi, geometri, ukuran, dan skalanya, baik dalam dua dimensi maupuan tiga dimensi.

d. Gambaran visual

e. Sebuah place seharusnya memiliki suatu citra yang menarik. Artinya, sebuah tempat yang berkualitas tinggi mempunyai ciri khas yang berasal dari interaski antara ruang dan bentuk, antara yang buatan dan yang alami, antara yang lama dan yang baru, antara yang formal dan yang bebas.

\subsection{Elemen Fasade Bangunan}

Elemen-elemen yang menyusun fasade bangunan sangat beragam, yaitu kepala, badan, dan kaki bangunan. Di samping itu, fasade bangunan juga disusun oleh komposisi bukaan-bukaan seperti jendela, pintu, dan ventilasi.

\subsection{Golden Section}

Sistem proporsi dalam arsitektur adalah sistem sebuah rasio karakteristik suatu kualitas permanen yang disalurkan dari satu rasio ke rasio lainnya untuk membentuk suatu hubungan visual yang konsisten antara bagian-bagian bangunan seperti halnya antara komponen-komponen bangunan dan bangunan secara menyeluruh (Ching, 2000:284). Salah satu teori proporsi dalam arsitektur yang umum digunakan yaitu golden section. Golden section didefinisikan sebagai rasio antara dua bagian dari sebuah garis atau dua buah ukuran suatu gambar bidang dimana bagian yang lebih kecil dibandingkan dengan bagian yang lebih besar adalah sama dengan perbandingan bagian yang besar terhadap keseluruhannya. Hal itu dapat ditunjukkan secara aljabar dengan persamaan dua rasio: $a / b=b / a+b$.

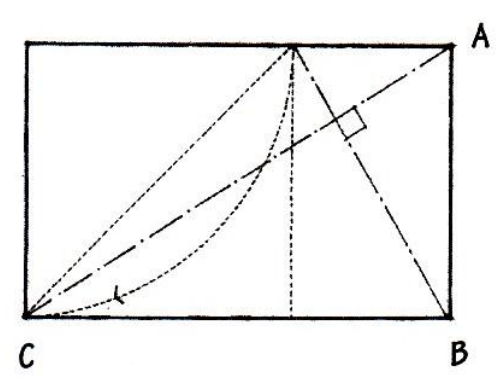

Gambar 1. Konstruksi geometrik golden section

(Sumber: Ching, 2000:286)

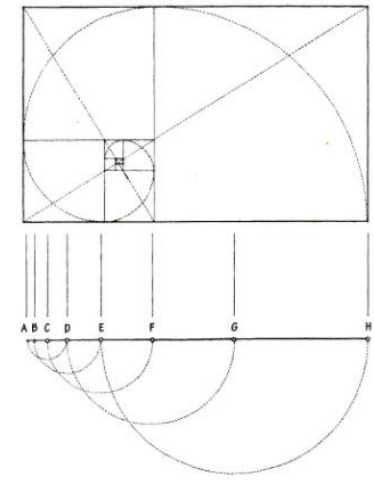

Gambar 2. Komposisi "segiempat emas" dalam golden section

(Sumber: Ching, 2000:287)

\subsection{Metode Penelitian}

Data penelitian diperoleh dan dikumpulkan melalui observasi lapangan yaitu dengan pengamatan, pengukuran, penggambaran dan dokumentasi fasade bangunan-bangunan di wilayah studi kasus. Adapun alat yang digunakan dalam observasi ini utamanya yaitu distance meter untuk memperoleh akurasi dimensi-dimensi fasade bangunan maupun 
dimensi-dimensi elemen-elemen pada fasade bangunan yang menjadi variabel penelitian. Selanjutnya data-data tersebut digambarkan secara digital menggunakan software desain AutoCAD, sketch-up, dan corel draw/photoshop. Penggambaran digital itu untuk mempermudah analisis proporsi golden section serta untuk memudahkan proses simulasi proporsi apabila ditemukan hasil yang tidak sesuai dengan golden section.

Data-data yang telah terkumpul dan didokumentasikan di dalam tahap pengumpulan data selanjutnya dianalisis mengenai kesesuaian proporsi fasade bangunannya menggunakan teori golden section. Analisis tersebut dilakukan dengan mengevaluasi proporsi antara kepala, badan, dan kaki bangunan maupun proporsi antara bukaan-bukaan adap tiga komponen tersebut maupun terhadap keseluruhan fasade bangunan. Apabila hasil analisis ada yang menunjukkan ketidaksesuaian dengan teori proporsi golden section, maka peneliti membuat simulasi desain dengan teori tersebut terhadap fasade bangunan yang bersangkutan hingga diperoleh proporsi yang tepat.

\section{Hasil dan Pembahasan}

3.1 Analisis Golden Section pada Fasade Bangunan di Kayutangan, Malang

Tahapan analisis golden section pada fasade bangunan di Kayutangan, Malang ini membagi wilayah studi menjadi dua bagian yaitu koridor jalan sisi Timur dan Barat sebagai berikut:

1. Bangunan-bangunan di koridor jalan sisi Timur

Jajaran bangunan di koridor ini dibagi menjadi segmen 1, segmen 2, dan segmen 3.

2. Bangunan-bangunan di koridor jalan sisi Barat

Jajaran bangunan di koridor ini dibagi menjadi segmen 4, segmen 5, dan segmen 6.

Segmen 1 dimulai dari bangunan restoran cepat saji Mc Donald's yang merupakan bangunan komersial. Analisis golden section pada fasade bangunan tersebut ditunjukkan dalam gambar berikut ini:

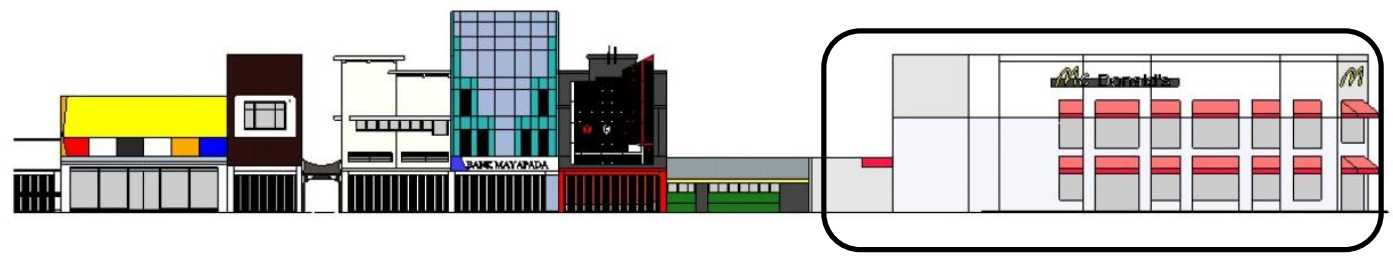

Segmen 1

Gambar 3. Fasade bangunan di segmen 1

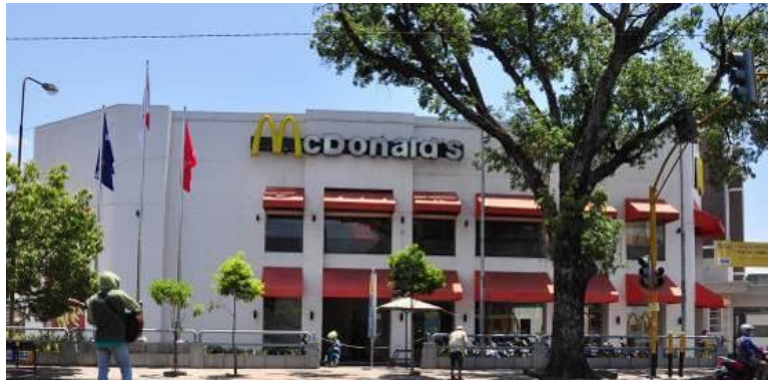

Gambar 4. Foto fasade bangunan di segmen 1 (restoran cepat saji Mc Donald's)
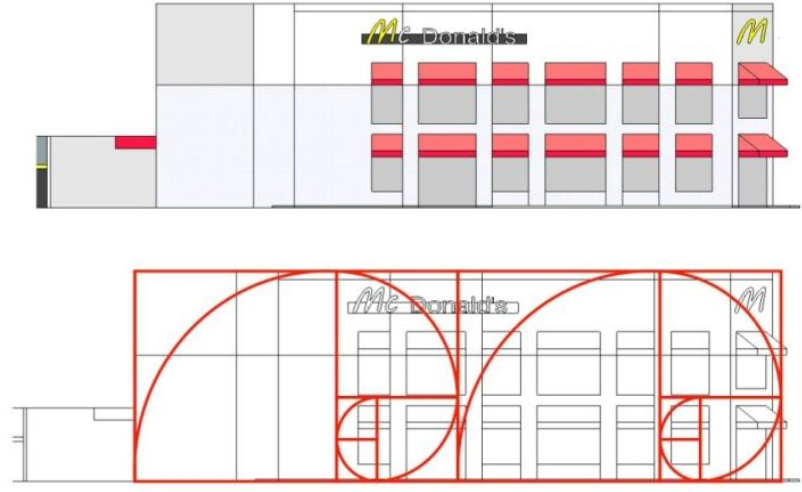

Gambar 5. Hasil analisis golden section pada fasade bangunan di segmen 1 
Analisis golden section pada fasade bangunan di segmen 1 menunjukkan bahwa proporsi lebar dan tinggi bangunan tersebut telah sesuai dengan golden section.

Dalam segmen 2 terdapat 6 (enam) bangunan yang dianalisis, dimana 5 (lima) bangunan merupakan bangunan komersial serta 1 (satu) bangunan perkantoran. Hasil analisis menunjukkan bahwa keenam fasade bangunan di segmen 2 seluruhnya tidak sesuai dengan golden section.

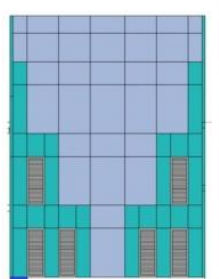

BANK MAYAPADA

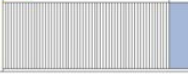

Fasade bangunan perkantoran (bank Mayapada), 3 lantai, tidak sesuai dengan golden section
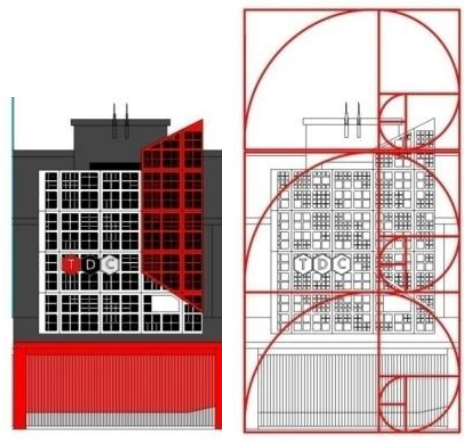

Fasade bangunan komersial (toko), 2 lantai, tidak sesuai dengan golden section

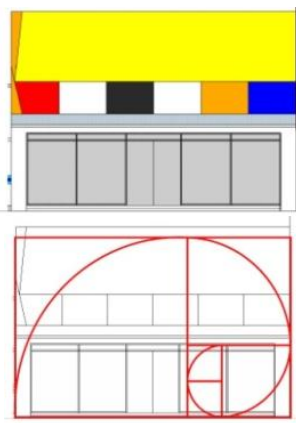

Fasade bangunan komersial (toko), 2 lantai, tidak sesuai dengan golden section

Gambar 6. Contoh hasil analisis golden section pada fasade bangunan di segmen 2

Fasade bangunan yang dianalisis di segmen 3 sebanyak 10 (sepuluh) bangunan, dimana 9 (sembilan) bangunan merupakan bangunan komersial serta 1 (satu) bangunan perkantoran. Seluruh fasade bangunan di segmen 3 ini seluruhnya juga tidak sesuai dengan golden section. Sedangkan di segmen 4 terdapat 5 (lima) bangunan, dimana 4 (empat) bangunan merupakan bangunan komersial serta 1 (satu) bangunan perkantoran. Hasil analisis menunjukkan bahwa kelima fasade bangunan di segmen 4 tidak sesuai dengan golden section.
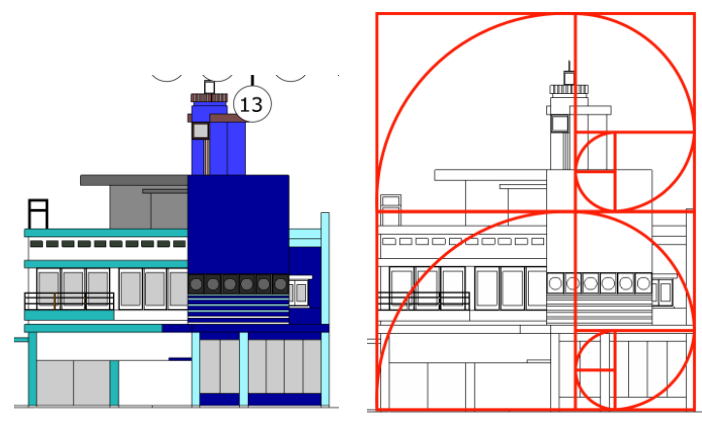

Gambar 7. Contoh hasil analisis golden section pada fasade bangunan di segmen 3
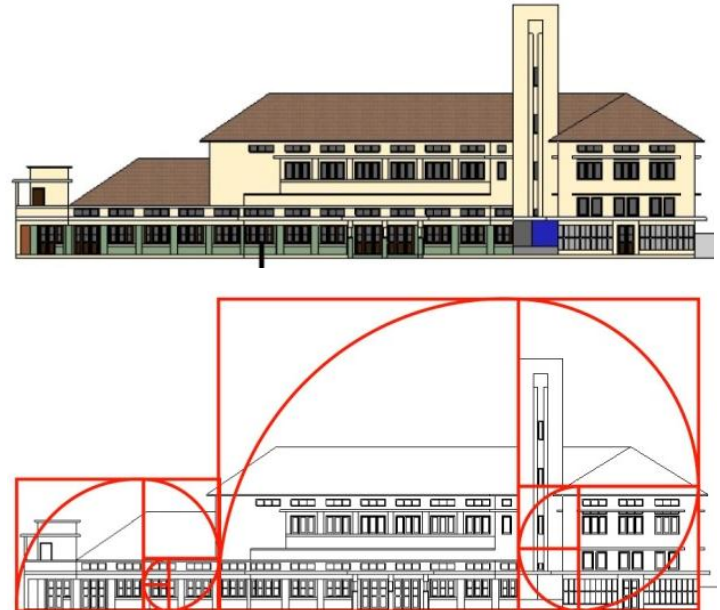

Gambar 8. Contoh hasil analisis golden section pada fasade bangunan di segmen 4 
Segmen 5 menganalisis 10 (sepuluh) bangunan, dimana 9 (sembilan) bangunan merupakan bangunan komersial serta 1 (satu) bangunan perkantoran. Seluruh fasade bangunan di segmen 5 tersebut juga memiliki proporsi lebar dan tinggi bangunan yang tidak sesuai dengan golden section. Adapun segmen 6 terdiri dari 1 (satu) bangunan perkantoran yaitu bank BCA. Hasil analisis menunjukkan bahwa fasade bank BCA tidak sesuai dengan golden section.
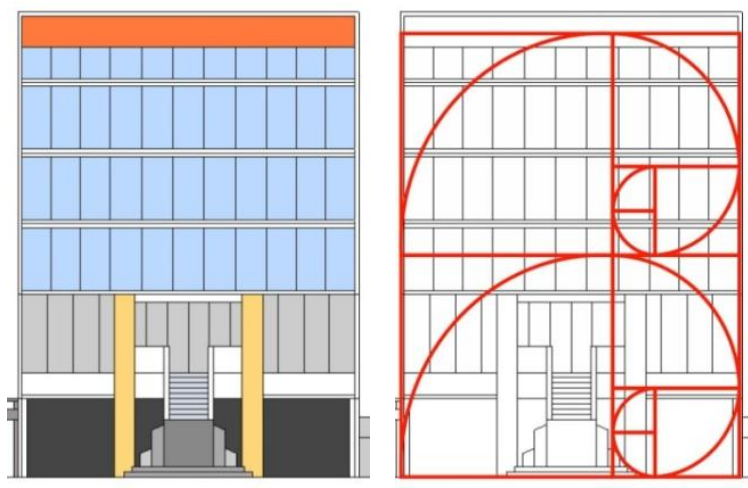

Gambar 9. Contoh hasil analisis golden section pada fasade bangunan di segmen 5
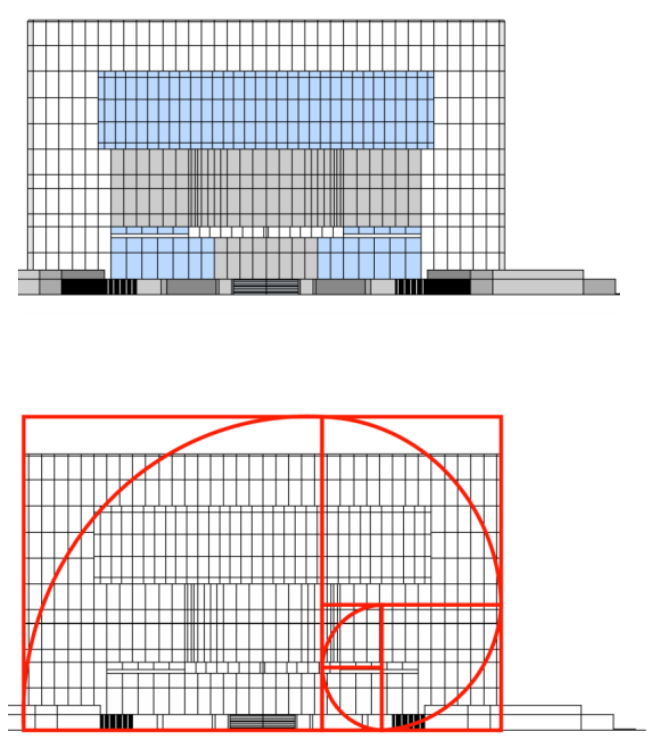

Gambar 10. Contoh hasil analisis golden section pada fasade bangunan di segmen 6

\subsection{Rekomendasi Desain untuk Fasade Bangunan yang Tidak Sesuai dengan Golden Section}

Hasil analisis golden section pada proporsi lebar dan tinggi fasade bangunan di kawasan Kayutangan, Malang sebagaimana diuraikan dalam sub bab 5.2.1 sampai dengan 5.2.6 menunjukkan bahwa $90 \%$ fasade bangunan tidak sesuai dengan golden section. Sehubungan dengan hasil analisis tersebut, tabel berikut ini memberikan rekomendasi desain khususnya berkaitan dengan penambahan atau pengurangan tinggi fasade bangunan yang sesuai dengan golden section.

\section{Kesimpulan}

Bangunan kolonial di Kayutangan, Malang terdiri dari bangunan perkantoran dan bangunan komersial. Hasil analisis menunjukkan bahwa fasade bangunan di Kayutangan, Malang $10 \%$ memiliki proporsi lebar dan tinggi bangunan sesuai dengan golden section dan $90 \%$ tidak sesuai dengan golden section. Pencapaian proporsi fasade bangunan di Kayutangan, Malang yang sesuai dengan golden section dapat dilakukan dengan penambahan atau pengurangan tinggi bangunan, sehingga dapat menciptakan tampilan estetika kota yang lebih baik. 


\section{Daftar Pustaka}

Adi, Adri. 2013. http://www.adri1618.com/2013/11/elemen-elemen-fasade-bangunan.html (diunduh: 14 April 2014, 22.15 WIB)

Ching, Francis D.K. 2000. Arsitektur: Bentuk, ruang, dan tatanan. Edisi Kedua. Jakarta: Erlangga

Fauziah, Nur., Antariksa, \& Ernawati, Jenny. 2012. Kualitas Visual Fasade Bangunan Modern Pasca Kolonial di Jalan Kayutangan Malang. Jurnal RUAS, Volume 10 No. 2, Desember 2012. www.google.com (diunduh: 14 April 2014, 22.00 WIB)

Heryanto, Bambang. 2011. Roh dan Citra Kota: Peran perancangan kota sebagai kebijakan publik. Surabaya: Brilian Internasional

Putri, Ragil Y.A. 2014. Arahan penataan fasade koridor jalan basuki rahmat kota Malang. Skripsi. Tidak diterbitkan

Sugiyono. 2012. Metode Penelitian Kombinasi (Mixed Methods). Bandung: CV. Alfabeta

Zahnd, Markus. 2009. Perancangan Kota Secara Terpadu: Teori perancangan kota dan penerapannya. Semarang: Soegijapranata University PressBagus, IGN. editor Koentjaraningrat. 1987). "Kebudayaan Bali” dalam Manusia dan KebudayaanIndonesia, cetakan 11, Jakarta: Djambatan 
Tabel 1. Rekomendasi desain untuk fasade bangunan yang tidak sesuai dengan golden section

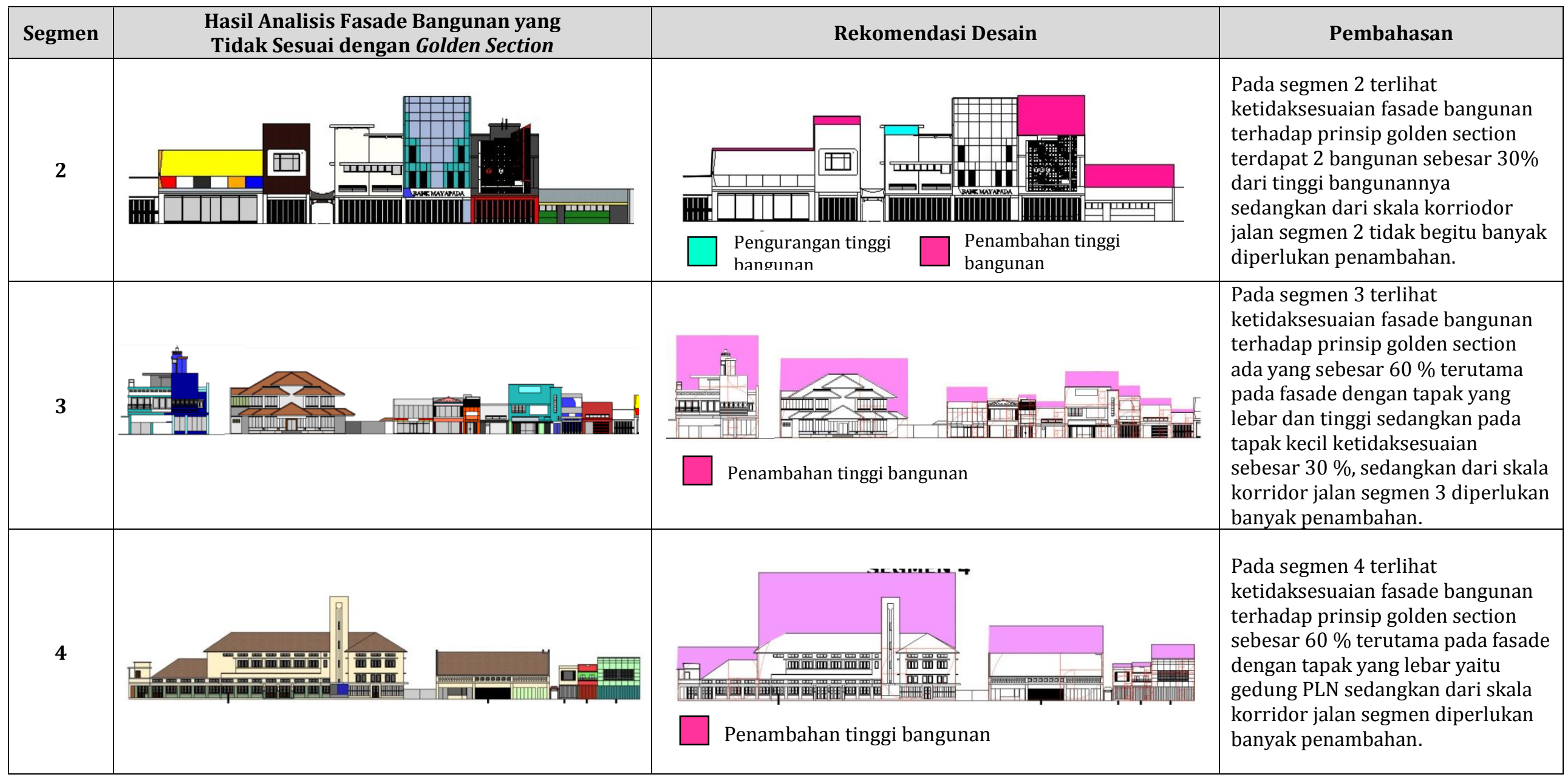


Lanjutan tabel 1

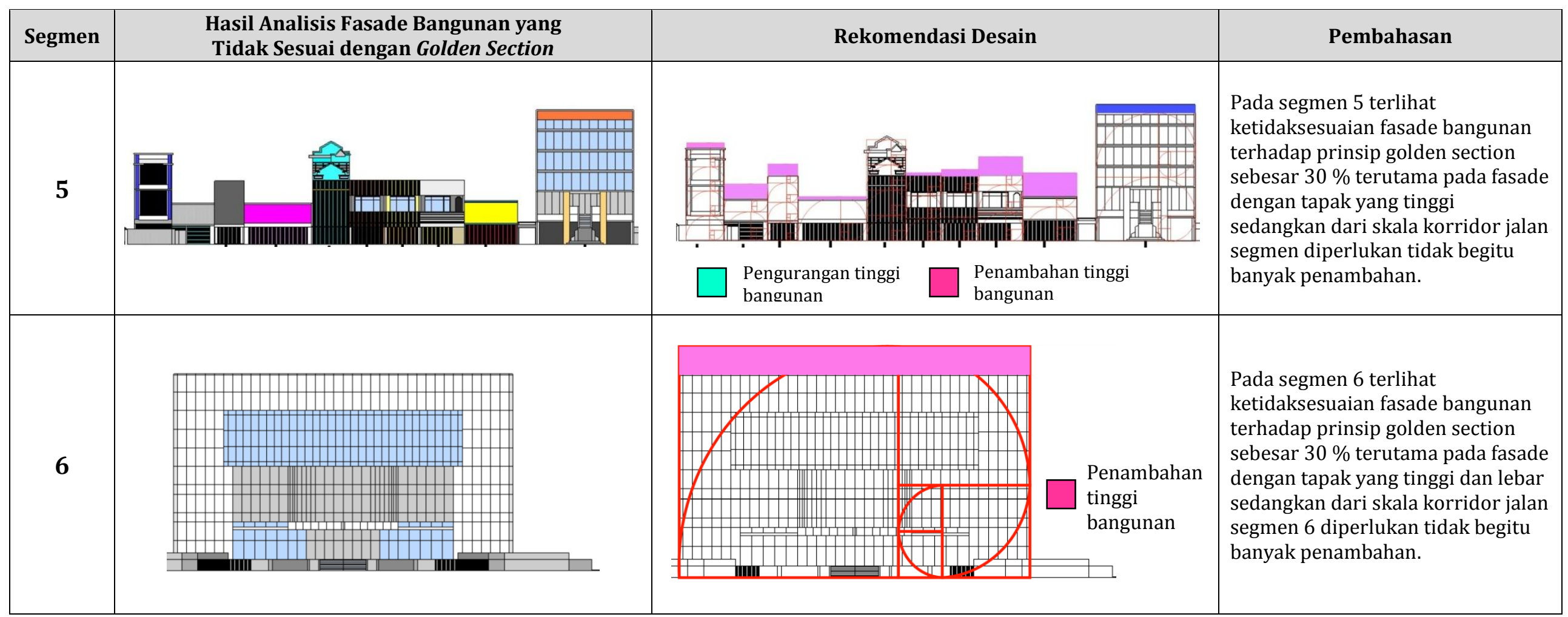

